\title{
Heats of Combustion and Formation of Cyclopropane ${ }^{1}$
}

\author{
By John W. Knowlton ${ }^{2}$ and Frederick D. Rossini
}

\begin{abstract}
The data of this investigation give $\Delta H c^{\circ}=-2091.38 \pm 0.54$ absolute kilojoules (or $-499.85 \pm 0.13 \mathrm{kcal}$ ) per mole, at $25^{\circ} \mathrm{C}$ for the heat of combustion of gaseous cyclopropane in oxygen to form gaseous carbon dixoide and liquid water. With this value, the heat of formation of gaseous cyclopropane, from solid carbon (graphite) and gaseous hydrogen each in its thermodynamic standard reference state, is calculated to be $\Delta H f^{\circ}=+12.74$ $\pm 0.14 \mathrm{kcal} / \mathrm{mole}$, at $25^{\circ} \mathrm{C}$. The heat of isomerization of gaseous cyclopropane into gaseous propylene is calculated to be $\Delta H^{\circ}=-7.86 \pm 0.18 \mathrm{kcal} / \mathrm{mole}$, at $25^{\circ} \mathrm{C}$.
\end{abstract}

\section{Introduction}

Two determinations of the heat of combustion of cyclopropane are reported in the literature; one by Thomsen $[1]^{3}$ in 1886 and one by Berthelot and Matignon [2] in 1893. The values differ by $7.5 \mathrm{kcal} / \mathrm{mole}$ or 1.5 percent of the measured value. Because of the increasing importance of cyclopropane in science and industry, it was desirable to determine the heat of combustion of cyclopropane with present-day apparatus and materials. This report gives the results of measurements of the heat of combustion of cyclopropane and calculations of its heat of formation from the elements and its heat of isomerization to propylene.

\section{Unit of Energy, Molecular Weights, Uncertainties}

The unit of energy upon which values reported in this paper are based is the absolute joule, derived from mean solar seconds and absolute ohms and volts, in terms of which certification of standard resistors and cells is made by this Bureau. For conversion to the conventional thermochemical calorie, the following relation is used $[3,4]$ :

$$
1 \text { calorie }=4.1840 \text { absolute joules. }
$$

The molecular weight of water, the mass of which was used to determine the amount of

\footnotetext{
1 This investigation was completed in 1940 , but the preparation of the results for publication was delayed by the transfer of the senior author to work in the U. S. Bureau of Agricultural and Industrial Engineering and the U. S. Bureau of Mines.

2 Deceased.

3 Figures in brackets indicate the literature references at the end of this paper.
}

reaction, was taken as 18.0160 from the 1947 table of international atomic weights [5].

The uncertainties assigned to the various quantities dealt with in this paper were derived, where possible, by a method previously described [6].

\section{Method, Apparatus, and Materials}

The same method and apparatus were used as in the investigation on the heat of combustion of propylene previously reported by the same authors [7].

The cyclopropane was prepared from commercial cyclopropane of anesthetic grade manufactured by the Monsanto Chemical Co. In this laboratory, the cyclopropane was purified by fractional distillation with the same apparatus and procedure as was used for propylene [7]. The center half of the distillate was selected as the "best" portion. The purity of this cyclopropane was determined from measurements of freezing points, according to a procedure previously described $[8,9,10]$, with the following results: freezing point of the actual sample, in air at 1 atmosphere, -127.53 $\pm 0.01 \mathrm{deg} \mathrm{C}$; calculated freezing point for zero impurity, in air at 1 atmosphere, $-127.42 \pm 0.04$ deg C; calculated amount of impurity, $0.0034 \pm$ 0.0012 mole fraction. It is calculated that the effect on the heat of combustion of this amount of the most probable impurity, propylene, would be 0.005 percent.

In the combustion of cyclopropane, the products contained carbon monoxide in an amount, on the average, corresponding to $0.00028 \pm 0.00007$ 
TABLE 1. Calorimetric results of the electrical energy experiments for cyclopropane

\begin{tabular}{|c|c|c|c|c|c|c|c|c|}
\hline \multirow{2}{*}{$\begin{array}{l}\text { Number of } \\
\text { experiments }\end{array}$} & \multirow{2}{*}{$\Delta R^{1}$} & \multirow{2}{*}{$k$} & \multirow{2}{*}{$K$} & \multirow{2}{*}{$U$} & \multirow{2}{*}{$\begin{array}{l}\text { Electrical } \\
\text { energy }{ }^{2}\end{array}$} & \multirow{2}{*}{$\begin{array}{l}\text { Mass of calo- } \\
\text { rimeter water }\end{array}$} & \multicolumn{2}{|c|}{$\begin{array}{l}\text { Energy equivalent calorim- } \\
\text { etèr system }^{3}\end{array}$} \\
\hline & & & & & & & Mean & $\begin{array}{l}\text { Standard } \\
\text { deviation of } \\
\text { the mean }\end{array}$ \\
\hline 12 & $\begin{array}{c}\text { Ohm } \\
0.389772 \\
\text { to } \\
0.413989\end{array}$ & $\begin{array}{c}\min ^{-1} \\
0.001949 \\
\text { to } \\
0.002000\end{array}$ & $\begin{array}{c}\text { Ohm } \\
0.009668 \\
\text { to } \\
0.010434\end{array}$ & $\begin{array}{c}\text { Ohm } \\
0.000234 \\
\text { to } \\
0.001080\end{array}$ & $\begin{array}{c}a b s j \\
57,087.5 \\
\quad \text { to } \\
60,918.3\end{array}$ & $\begin{array}{c}g \\
3542.85 \\
\text { to } \\
3551.41\end{array}$ & $\begin{array}{l}\text { abs } j / o h m \\
150,746.2\end{array}$ & $\begin{array}{r}\text { abs } j / \text { ohm } \\
\quad \pm 9.9\end{array}$ \\
\hline
\end{tabular}

1 The average temperature of the calorimeter was between $24.97^{\circ}$ and $25.03^{\circ} \mathrm{C}$ in all experiments except one in which the average temperature was $25.09^{\circ} \mathrm{C}$. 2 The time of electrica! energy input was $1500.00 \mathrm{sec}$. in each experiment except one where the time was 1440.00 sec.

${ }^{3}$ Adjusted to $3550.00 \mathrm{~g}$ of water and an average temperature of $25.00^{\circ} \mathrm{C}$.

TABLE 2. Calorimetric results of the reaction experiments for cyclopropane

\begin{tabular}{|c|c|c|c|c|c|c|c|c|c|c|}
\hline \multirow{2}{*}{$\begin{array}{l}\text { Number of } \\
\text { experi- } \\
\text { ments }\end{array}$} & \multirow{2}{*}{$\Delta R^{1}$} & \multirow{2}{*}{$k$} & \multirow{2}{*}{$K$} & \multirow{2}{*}{$U$} & \multirow{2}{*}{$\begin{array}{c}\text { Electrical } \\
\text { energy } \\
\text { equivalent } \\
\text { of calorim- } \\
\text { eter } \\
\text { system 2 }\end{array}$} & \multirow{2}{*}{$\begin{array}{l}\text { "Gas" } \\
\text { energy } 3\end{array}$} & \multirow{2}{*}{$\begin{array}{l}\text { "Vapori- } \\
\text { zation" } \\
\text { energy }\end{array}$} & \multirow{2}{*}{$\begin{array}{c}\text { Mass of } \\
\text { water formed } \\
\text { in the re- } \\
\text { action }{ }^{4}\end{array}$} & \multicolumn{2}{|c|}{$\begin{array}{l}\text { Heat of combustion }{ }^{5} \\
\qquad(-\Delta H c)\end{array}$} \\
\hline & & & & & & & & & Mean & $\begin{array}{l}\text { Standard } \\
\text { deviation } \\
\text { of the mean }\end{array}$ \\
\hline 14 & $\begin{array}{c}\text { Ohm } \\
0.395633 \\
\text { to } \\
0.397962\end{array}$ & $\begin{array}{c}\min ^{-1} \\
0.001951 \\
\text { to } \\
0.001999\end{array}$ & $\begin{array}{c}\text { Ohm } \\
0.009555 \\
\text { to } \\
0.010429\end{array}$ & $\begin{array}{c}\text { Ohm } \\
0.000237 \\
\text { to } \\
0.000609\end{array}$ & $\begin{array}{c}\text { abs } \mathrm{j} / \mathrm{Ohm} \\
150,453 \\
\text { to } \\
150,833\end{array}$ & $\begin{array}{c}j \\
-5.3 \\
\text { to } \\
11.7\end{array}$ & $\begin{array}{c}j \\
-268.8 \\
\text { to } \\
-310.0\end{array}$ & $\begin{array}{l}g \\
\text { 1. } 50845 \\
\quad \text { to } \\
\text { 1. } 51795\end{array}$ & $\begin{array}{c}\text { abs } \mathrm{kj} / \text { mole } \\
2091.33\end{array}$ & $\begin{array}{c}\text { abs } \mathrm{kj} / \mathrm{mole} \\
\quad \pm 0.18\end{array}$ \\
\hline
\end{tabular}

1 The average temperature of the calorimeter was between $25.01^{\circ}$ and $25.02^{\circ} \mathrm{C}$ in all experiments.

2 Corrected to the actual mass of water in the calorimeter can in each experiment and including the heat capacity of one-half the mass of water condensed in the reaction.

${ }^{3}$ The "ignition" energy was $22.4 \mathrm{j}$ in each experiment except in two experiments where it was $31.4 \mathrm{j}$ and $33.6 \mathrm{j}$ due to the use of sparking times of 14 and 15 sec, respectively, instead of the usual 10 sec.

4 The amount of reaction was determined from the mass of water formed in the combustion.

${ }^{5}$ Includes a correction of $+0.011 \pm 0.003$ percent because of the presence of a small amount of carbon monoxide in the exit gases.

mole fraction of the total carbon. ${ }^{4}$ This necessitated a correction (see next section) of +0.011 \pm 0.003 percent to the observed heat evolved in the calorimetric combustion experiments in order to obtain the heat that would have been evolved had all the carbon appeared as carbon dioxide. In eleven experiments in which the masses of water and carbon dioxide formed in the combustion were determined, with correction made for the 0.00028 mole fraction of carbon not formed as carbon dioxide, the mean value of the ratio of the number of moles of carbon dioxide to the number of moles of water was 0.99989 with a standard deviation of \pm 0.00006 .

\section{Results}

The experimental results on the determination of the energy equivalent of the calorimeter system are summarized in table 1, which gives the following data: the number of experiments performed; the minimum and maximum values of

4 The tests for carbon monoxide were kindly made by E. C. Creitz of the Gas Chemistry Section of this Bureau.
$\Delta R, k, K, U$, electrical energy, mass of calorimeter water; and the energy equivalent of the calorimeter system, the mean value of the energy equivalent of the calorimeter system and its deviation. The symbols have the same significance as in earlier reports $[7,13]$.

The "ignition energy" was determined to be 22.4 joules for a time of sparking of $10 \mathrm{sec}$.

The experimental result of the calorimetric combustion experiments are summarized in table 2 , which gives the following data: the number of experiments; the minimum and maximum values of $\Delta R, k, K, U$, energy equivalent of the calorimeter system (calculated from the mean value as given in table 1, corrected to the actual mass of water in the calorimeter can in each experiment, and including one-half the mass of water condensed in the reaction), "gas" energy, "vaporization" energy, mass of water formed; and the mean value of the heat of combustion in absolute kilojoules/mole cyclopropane and its standard deviation.

Conversion of the observed mean value of the 
heat of combustion to the value for the standard heat of combustion, with each substance in its thermodynamic standard state, involves addition of 0.05 kilojoules/mole to the mean value of $-\Delta H c$ given in table 2 . This correction is taken to be the same as that for propylene [11]. Accordingly, the present investigation yields for the standard heat of combustion at $25^{\circ} \mathrm{C}$ :

$\mathrm{C}_{3} \mathrm{H}_{6} \quad$ (gas, cyclopropane) $+4 \frac{1}{2} \quad \mathrm{O}_{2} \quad$ (gas) $=3 \mathrm{CO}_{2}$ (gas) $+3 \mathrm{H}_{2} \mathrm{O}$ (liquid);

$\Delta H c^{\circ}{ }_{298 \cdot 16}=-2091.38 \pm 0.54$ kilojoules $/$ mole or $-499.85 \pm 0.13 \mathrm{kcal} /$ mole $(1)$.

Combination of the value in eq 1 with the values for the heats of formation of water and carbon dioxide [12] yields for the standard heat of formation at $25^{\circ} \mathrm{C}$ :

$3 \mathrm{C}$ (solid, graphite) $+3 \mathrm{H}_{2}$ (gas) $=\mathrm{C}_{3} \mathrm{H}_{6}$ (gas, cyclopropane);

$$
\Delta H f^{\circ}{ }_{298 \cdot 16}=+12.74 \pm 0.14 \mathrm{kcal} / \mathrm{mole} .
$$

Combination of the value in eq 2 with the value for the heat of formation of propylene [11] yields for the heat of isomerization of cyclopropane into propylene:

$\mathrm{C}_{3} \mathrm{H}_{6}$ (gas, cyclopropane) $=\mathrm{C}_{3} \mathrm{H}_{6}$ (gas, propylene) ;

$$
\Delta H^{\circ}{ }_{298 \cdot 16}=-7.86 \pm 0.18 \mathrm{kcal} / \mathrm{mole} .
$$

Comparison of the results of the present investigation with the data previously reported by Thomsen [1] and Berthelot and Matignon [2] is given in table 3 .
TABLE 3. Comparison of the present with previous results

\begin{tabular}{|c|c|c|}
\hline Investigators & $\begin{array}{l}\text { Heat of combus- } \\
\text { tion of cyclo- } \\
\text { propane, } \Delta H, \text { at } \\
\text { at } 25^{\circ} \mathrm{C}\end{array}$ & $\begin{array}{l}\text { Heat of isomeriza- } \\
\text { tion of cyclo- } \\
\text { propane to pro- } \\
\text { pylene, } \Delta H \text { at } \\
25^{\circ} \mathrm{C}\end{array}$ \\
\hline $\begin{array}{l}\text { Thomsen [1] } \\
\text { Berthelot and Matignon [2] } \\
\text { Present }\end{array}$ & $\begin{array}{l}\text { kcal/mole } \\
-499.2 \\
-506.7 \\
-499.85 \pm 0.13\end{array}$ & $\begin{array}{l}\text { kcal/mole } \\
-7.0 \\
-7.8 \\
-7.86 \pm 0.18\end{array}$ \\
\hline
\end{tabular}
on cyclopropane

\section{References}

[1] J. Thomsen, Thermochemische Untersuchungen IV (Barth, Leipzig, 1886).

[2] M. Berthelot and C. Matignon, Ann. Chim. Phys. [6] 30, 561 (1893).

[3] E. F. Mueller and F. D. Rossini, Am. J. Phys. 12, 1 (1944).

[4] Selected Values of Chemical Thermodynamic Properties. Values of constants (National Bureau of Standards, Dec. 31, 1947).

[5] G. P. Baxter, M. Guichard, and R. Whytlaw-Gray, J. Am. Chem. Soc. 69, 734 (1947).

[6] F. D. Rossini and W. E. Deming, J. Wash. Acad. Sci. 29, 416 (1939).

[7] F. D. Rossini and J. W. Knowlton, J. Research NBS 19, 249 (1937) RP1024.

[8] A. R. Glasgow, Jr., A. J. Streiff, and F. D. Rossini, J. Research NBS 35, 355 (1945) RP1676.

[9] A. R. Glasgow, Jr., N. C. Krouskop, J. Beadle, G. D. Axilrod, and F. D. Rossini, Anal. Chem. 20, 410 (1948).

[10] B. J. Mair, A. R. Glasgow, Jr., and F. D. Rossini, J. Research NBS 26, 591 (1941) RP1397.

[11] E. J. Prosen and F. D. Rossini, J. Research NBS 36, 269 (1946) RP1702.

[12] D. D. Wagman, J. E. Kilpatrick, W. J. Taylor, K. S. Pitzer, and F. D. Rossini, J. Research NBS 34, 143 (1945) RP1634.

[13] F. D. Rossini, BS J. Research 6, 1 (1931) RP 259; \%, 329 (1931) RP343.

WAshington, March 24, 1949. 